\title{
紙の評価について
}

製紙科学研究所 門 屋卓

\section{On the Evaluation of Paper}

\author{
Takashi Kadoya
}

Paper Science Research Laboratory

This paper is described on the critical view how to evaluate the behavior of papers.

In order to measure the fundamental properties of paper in accurately, first of all, we should carefully measure the moisture content and thickness of paper considerin grelative humidity-temperature dependence and surface roughness influences.

The subjective evaluation of stiffness of paper not only depend on the elastic modulus and caliper of paper but also the balance of these two factors. In addition, this paper discusses the permanence of paper. In spite of much research works and even though the factor which cause ageing are fairly cliar, it is still impossible to predict with precision the permanence of individual paper samples using artificial test. This paper also introduce the subjective evaluation of degradated paper by five level of Excellent (4 point), Good ( 3 point), Fair (2 point), Brittle (1 point) and Very Brittle ( 0 point) which are proposed by Japanese Library Committee.

Finally, the typical results of subjective evaluation of 8 terms for 9 kinds of commercial printing papers $\left(64 \mathrm{~g} / \mathrm{m}^{2}\right)$ are presented.

Keywords : Paper properties, moisture dependency, temperature dependency, stiffness, subjective evaluation, permanence of paper.

\section{1.はじめに}

今年の 6 月 7 日から 9 日まで金沢工業大学で「資料 の保存, 劣化防止怙よび修復等阔する国際セミナ -」('84 International Seminar on Preservation, Conservation, and Restoration of Materials) と言 ら変った会合が開催され筆者は講師の一人として参加 した。このセミナーの目的は現在各国の図書館で大き な問題となっている蔵書の保存をいかにすべきかと言 らことを中心開かれたものであり，海外からは米国 因書館振興財団, ニューヨーク公共図書館, コロンビ ア大学図書館学校などの専門家が講師として招かれ，

\footnotetext{
本文は第 14 回㵶維学会夏期セミナー（昭和 56 年） で講演した内容の一部を大幅に加筆してまとめたもの である。
}

日本からは筆者の他に機能紙研究会・前松氏, 富士フ イルム秝・笹森氏, 国文学研究資料館・安沢教授, 牧 製本印刷秼・牧氏と言う今までの紙パの会合には見ら れない顔よ゙れで約 200 名を超える参加者によって 3 日 間極めて有意義な発表と討論が行われた。

参加者のほとんどは大学, 公共機関の図書, 情報の 関係者であり紙パ関係では農工大・大江教授他数名を 数觉る程度であった。

$$
\text { ここではこのせミナーの詳細について報告するつる }
$$

りはない。しかし，3 日間のセミナー，パーティなど を通してこれらの多くの人々と交流する機会が得られ， 紙といら材料汶して我々以外飞極めて高い関心を持 ち紙の本質をさらに理解しょうとする多くの人々がい ることを知った。

紙は言らまでもなく長い歴史を持った材料であるが， その大量生産の技術が確立し自由に紙を使えるように 
なったのは 1800 年 Kellerkよるグラウンドパルプの 製法の発明からであり，ここで始めて木材と紙とのか かわり合いが生まれた。以来，木材を原料とする紙の 製法は次々と発展し現在の洋紙の時代を形造っている。

しかし，紙の量的製造法が確立し一般の人々に使わ れ始めた頃はまだ紙は貴重品として大事に使われてい たものと思われる。そこでの紙はどのように評価され その判定に基ついてビの上らな用途に向けられていた かを知ることは極めて興味のあるところである。そこ での紙は恐らく目でながめ，手で触り，折ったりちぎ ったりすることによってその紙が何に使えるかを判定 していたものと思われる。

紙の各種の製造法が開発され量的な普及が進むにつ れてその用途洽わせて独自の評価方法が出現し次々 と試験法が出来上って行った。だが，その試験法が正 しく紙の姿を現しているかと考えると多くの疑問が生 じることは紙を扱ら我々にとって常に経験することで ある。

このように考えると紙を正しく評価し理解すること は極めて重要なことであり，これからの紙の発展にも つながることではないかと考光る。

以上，いろいろなことをらまえて紙の評価について 幾つかの点を拾いあげ問題の提起としたい。

\section{2. 紙の試験方法の歴史}

物事が進歩する蔹には，それがどんな背景と根拠で， とんな発想で，どんなふらに展開して行ったか，いわ ゆる科学史的考察が必要であろうが，紙の評価法に関 して大綱としては幾つかの資料が見受けられるが，個 々のものについては残念ながら筆者にはその詳細な資 料はない。紙の試験方法に関してもこのような主旨で 一度はまとめて見る必要があると思われるが，ここで は「紙及びパルブ年表」(昭和 53 年) $)^{1)}$ から拾いあげ て見た。

前述のように，種々の試験機が出現する前の紙の評 洒は種々の感覚的方法によって行われ，それが意外之 正しい表現をしていたのではないかと思われる。本稿 では触れないが吒解度の判定も測定機が出現する前は 手の感覚で評価され吒解による原料の变化を微妙にと らえていたものと見なされる。

年表によれば，紙を本格的淀量化して測定しょう とする方法が出現したのは 1890 年ドイッのルイ・シ ョッパーによるショッパー型引張試験機である。この ことは, 1840 年の GP の製造より 50 年も後であり, 近代洋紙の主原料であるクラフトパルプ（1884 年ス ウェーデン Dahl）。発明より遅れること数年である
点興味深いものがあり, 試験機の出現が紙の引張強度 の定量化を背景にして始まったと推測することもでき る。

いま，同年表から代表的な紙の試験機が出現した時 期を抽出して見ると以下のようになる。

\begin{tabular}{|c|c|c|c|c|}
\hline 年代 & & 国籍 & 発明者 & 試験機の種類 \\
\hline 1890 & ト & イッ & $\begin{array}{l}\text { ルイ・ショッ } \\
\text { パ- }\end{array}$ & $\begin{array}{l}\text { ショッパー型引張 } \\
\text { 試験機 }\end{array}$ \\
\hline 97 & & $\prime \prime$ & $" \prime$ & $\begin{array}{l}\text { ショッパー型耐折 } \\
\text { 試験機 }\end{array}$ \\
\hline 909 & & $" \prime$ & テクル & ダイヤル式紙厚 \\
\hline 909 & 米 & 国 & ミューVン & 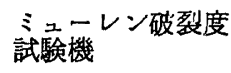 \\
\hline 912 & & " & サメット & 不透明度測定器 \\
\hline 915 & & $" \prime$ & I P C & $\begin{array}{l}\text { イソガソル光沢測 } \\
\text { 定法 }\end{array}$ \\
\hline 1920 & ド & $1 \%$ & $\begin{array}{l}\text { エレメンドル } \\
\text { フ }\end{array}$ & $\begin{array}{l}\text { エレメンドルフ引 } \\
\text { 裂試験法 }\end{array}$ \\
\hline 1920 & 米 & 国 & $\begin{array}{l}\text { ツイング・イ } \\
\text { ソツルメント } \\
\text { 社 }\end{array}$ & 同上試験機 \\
\hline 921 & & $" 1$ & $\begin{array}{l}\text { セントラル・ } \\
\text { サイェンテイ } \\
\text { ・フィック社 }\end{array}$ & $\begin{array}{l}\text { インガゾル光沢試 } \\
\text { 験機 }\end{array}$ \\
\hline 924 & & " & カーソン & $\begin{array}{l}\text { 紙のカール度測定 } \\
\text { 法 }\end{array}$ \\
\hline 1925 & & $" 1$ & $\begin{array}{l}\text { ヤュブソン・ } \\
\text { ホフマン }\end{array}$ & ゼロスパン測定機 \\
\hline 926 & $F$ & $1 \%$ & フェンチェル & $\begin{array}{l}\text { フェンチェル伸縮 } \\
\text { 試験機 }\end{array}$ \\
\hline 1930 & & $" 1$ & ペック & ベック平滑度試験 \\
\hline 1933 & 米 & 国 & $\begin{array}{l}\text { スナイダー及 } \\
\text { びカーソン }\end{array}$ & M I T 耐折試験機 \\
\hline 1934 & & " & カーソン & 透気度試験法 \\
\hline 935 & & $" \prime$ & クラーク & クラークこわさ試 \\
\hline 1936 & 米 & 国 & デェイビス & $\begin{array}{l}\text { チヤップマン平滑 } \\
\text { 試験法 }\end{array}$ \\
\hline 1938 & & " & ガーレ & $\begin{array}{l}\text { ガーレS P S 試験 } \\
\text { 器 }\end{array}$ \\
\hline 1938 & & $" \prime$ & $\begin{array}{l}\text { カークバドリ } \\
\text { ック及びウイ } \\
\text { リム }\end{array}$ & デニソンワックス \\
\hline 94 & & $"$ & ガードナー社 & ハンター光度計 \\
\hline & & ソダ & I G T & I G T 印刷適性 \\
\hline
\end{tabular}

この表から言えることは，紙の評洒はまずその力学 的測定を中心に始まり続いて紙の表面とかカールのよ らな印刷に結びつく測定法に移行し，その後さらにそ れをより詳細に検討しようとする測定法が提案されて いることに気がつく。さらに，紙の力学的性質をしら べる試験法たけに注目して見ると，引張強さ，破断伸 
び，破裂強さ，引裂強さ，耐折強さなどでありこれら はすへて破壊試験である。

紙の品質をこのよらな破壊試験だけで判定しよらと する習慣は，紙の実用的な面からの要求よりむしろ， 紙の製造と出荷という品質管理的前提に立って行われ ているものと考えられる。すなわち，紙の品質は原質 は勿諭のこと前処理の条件や抄紙時の変動によってそ の性質が大さく変化する。たとえば，同し原質でも吒 解の条件以よって前述の 5 つの破壊時の值や他の物理 的性質のバランスがかなり変化し，紙の技術者は永い 経験に基ついてこれを破壊といら最終值で判断し，製 造の指針を得るとともに出荷の基準として採用してい たものと考学られる1953 年初版の Pulp and Paper Manufacture ${ }^{2)}$ の第 5 章 Paper Testing の項の冒頭 飞 “Why paper is tested”という書き出しで(1)品質 改良への製造指針，(2)品質安定のための監視，(3)前の スペックを守っているか，と言う 3 点をあげて打り， 紙の用途を意識した試験については全く触れていない。

しかし，紙は実用面で破壊して使用するケースはま れであり，破壊が進むまでの過程とか，破壊前にどん な挙動を示すかが重要ではないかと考える。このよう に考兄ると紙の力学的評価として，他の材料分野で用 いられる応力ひずみ曲線を測定し，これより弾性率を 算出し示すこともかなり重要になってくるのではない かと思われる。しかし，このような基本的性質を求め るに当って紙と言う材料は極めて扱いにくい特徽を持 っている。これについて以下幾つかの項目をあげ述べ てみよう。

\section{3. 紙の水分，厚さ}

言らまでもなく，紙はきわめて吸湿性の高い材料で

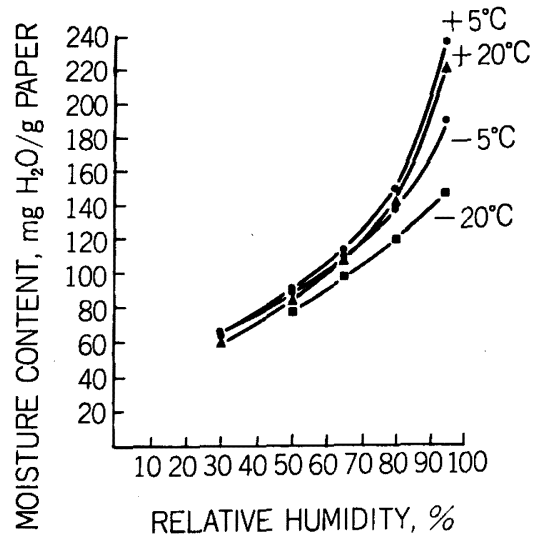

Fig. 1-1 Adsorption isotherms.
あり, 空気中の湿度の変化によって紙の含有水分は変 化しそ机応じて紙の物牲㹥変化する。紙の含水率は 当然大気の相対湿度によって変化するが，その場合温 度がどのように影響するかは類似の材料として木綿に

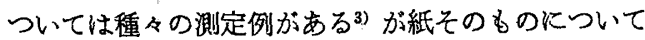
の例は極めて少ない。図1はクラフト紙（坪量に 70 $\left.\mathrm{g} / \mathrm{m}^{2}\right)$ ついて温度を $-20^{\circ} \mathrm{C} \sim+20^{\circ} \mathrm{C}$ の範囲で相対湿 度を $30 \%$ ９5\% まで変化させた場合の含水率の変化

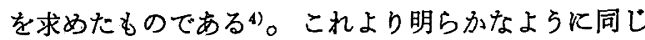
相対湿度の条件下でもそのとき温度が異なれば紙の 含水率は僅が異り，とくに相対湿度が高い場合は温 度の影響が大きく現われる。また図から明らかなよう に $0 \sim 5^{\circ} \mathrm{C}$ 近辺の温度で含水率のピークが見受けられ る。

また，紙の含水率の測定は JIS では $105 \pm 3^{\circ} \mathrm{C}$ の温 度下で $1 \sim 2$ 時間加熱し，測定を 2 回くり返したとき の質量差が $0.1 \%$ 以下となった場合の重量を絶乾重量 としているが，これを箃密な絶乾重量として扱えない 場合がしばしばある。すなわち，上記の条件で乾燥し た試料を減圧すると重量が減少する。このことは紙の 中にまだ水分が残っていることを意味する。さらに， かなり高温の場合でも乾燥機内の相対湿度が測定値に 影響することはよく知られており何をもって絶乾の基 準とするかは㛜密には定められない。

つぎに，紙の厚さの測定は紙の密度，比容積，弾性 率，紙のこしなどの算出には不可欠なものであり，と くに紙のこしに関して試料の断面二次モーメントを求 める計算には（厚さ）の 3 乗を求める必要があり，厚 さの測定精度が極めて重要な因子となる。

JIS による厚さの測定は一定面積の平行板で紙の内 面を一定圧力ではさみ，平行板の間隙を $0.002 \mathrm{~mm}$ ま

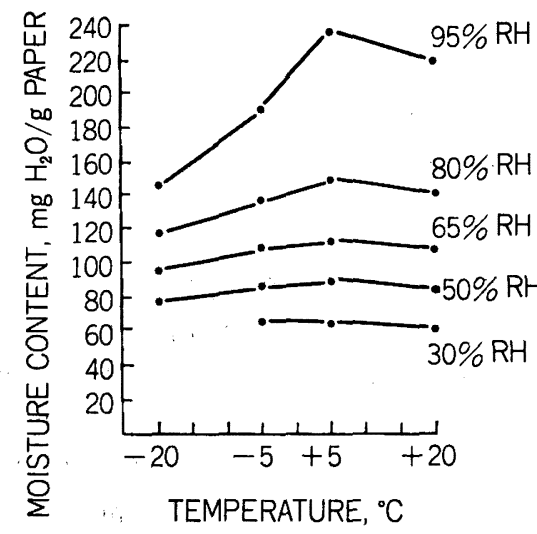

Fig. 1-2 Moisture content vs. temperature. 


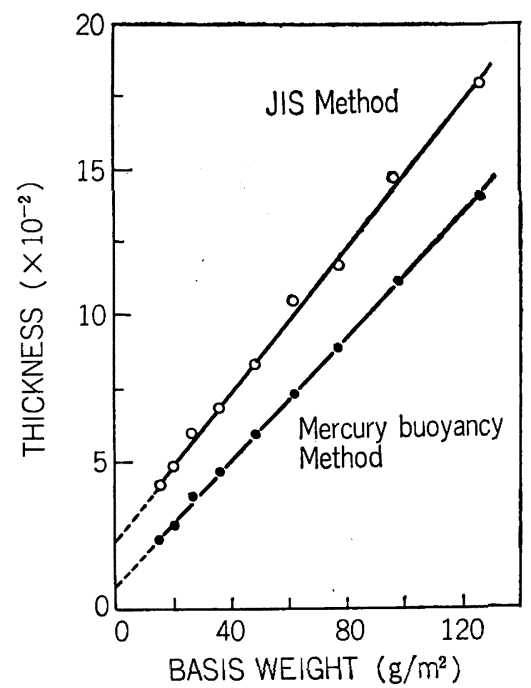

Fig. 2 Relation of Basis Weight and Thickness

で読みとることが明示されている。いま，同じパルプ 原料を坪量を変えて抄紙した試料の厚さを JIS に従っ て測定すると図 2 の白点のような直線となる。この直 線を外插した場合, 紙の坪量がゼロになっても“厚さ がある”と言う奇妙な結果が生れる。つまり，JISの 測定では紙の真の厚さを表していないことを意味する。 これは紙の表面の凹凸によるもので未吒解のパルプで 抄いた紙は凹凸が烈しいのでこの現象が強調され $30 \%$ の誤差を生ずるという報告も知られている55。

真の紙の厚さを求める方法についてはいろいろな方 法が提案されているが6,7) 水銀の浮力を利用する方法 によって比較的正確に厚みを求めることができ，これ を図 2 の黑点にて示した8)。この直線の外搟值はかな り原点に近いところを通過し JIS 法との違いを表して いる。JIS 法の厚さの測定は真の紙の厚さに対し厚目 な值が測定されているので，この誤差が前記の紙の密 度, 弾性率，こしなどの計算に食い違いが生じる1つ の因子となっている。

\section{4. 紙の曲げこわさ}

紙の特徵の一つは比較的高い弾性率にあるものと思 われる。その値は特殊な紙を除いて静的弾性率で 2 $8 \times 10^{10} \mathrm{dyne} / \mathrm{cm}^{2}$ 程度である。これに対してポリエ チレン（高圧法）は $4 \times 10^{9} \mathrm{dyne} / \mathrm{cm}^{?}$, 塩化ビニル (軟質) は $2 \times 10^{9} \mathrm{dyne} / \mathrm{cm}^{2}$, ポリスチレンは $1.2 \times$ $10^{10} \mathrm{dyne} / \mathrm{cm}^{2}$ といずれも紙より下趈る值であり，紙 が作業性, 加工性などの面でもフィルム類と違った存

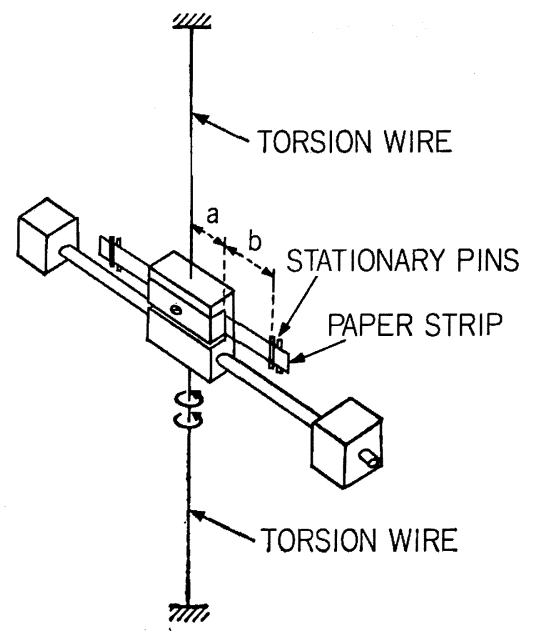

Fig. 3 Schematic Drawing of Torsion Pendulum.

在であることか゚これから分かる。

この值は直接紙の曲げこわさに関係し，いわゆる紙 のこしを決める重要な因子であるが，弾性率と言う值 は紙の実用試験といら面ではあまりとり挙げられてい ない。

最近伸びこわさと言ら表現が使われ始めているが10) 前述の試験方法の歴史で登場するのは 1935 年クラー ク試験機であり Paper Trade Journal 1935 年 3 月 号にClarkによって論文が発表されている11)。ここで はすでに現在使われている Stiffness $=L^{3} / 100$, Rigi$\operatorname{dity}=\mathrm{L}^{2} \mathrm{~W} / 10,000$ など紙のこわさの 4 つの表示法が 提案されている。さらに同誌 1940 年 2 月号にその検 討結果が発表されて扣り図 3 のような測定法との比較 が行われて扣り興味深い12)。図3は一種の㹉り振子で これに試料をとりつけ振動させたときの振子のふれか ら試料の曲げこわさを求めようとするもので

$$
E I=4 \pi^{2} I_{0}\left[b^{2} / 6(b+a)^{2}\right] \times\left[(1 / T)^{2}-\left(1 / T_{0}\right)^{2}\right]
$$

なる式によって曲げこわさ EI が求められている。た た゚し，Iは試料， I 0 は吊下質量の断面二次モーメント， $\mathrm{T} ， \mathrm{~T}_{0}$ は試片をとりつけた場合とはづした場合の振 子の振動周期である。クラーク試験機との比較の結果 はかなりの精度で一致しクラークの信頼性を示してい る。しかし，このような試験法の発想は極めて貴重な 資料である。

このように紙のこわさについての測定はかなり以前 から行われ，クラーク試験法以外テーバー，オルゼン など多くの測定機が出現し相互の比較がなされている 
が，測定值の物理的意味について検討した例は少ない。

クラークの Stiffness の場合 $\mathrm{L}^{3} / 100$ で表しこれは $\mathrm{ET}^{3} / 12 \mathrm{~W}$ K当り（Eは試料の弾性率，Tは紙の厚さ, Wは坪量)， $\mathrm{E}$ と Tを正確に求めれば両者の間に高い 相関が得られることは知られている9)。しかしWが一 定の場合，ある Stiffness の值に対し E とTの値は無 数飞存在する。いま， A， B， C……と言う紙があっ て $\mathrm{E} \times \mathrm{T}^{3}$ の值がすべて同じならばそれらの紙はすべ て同しこわさとして我々の手に感じるかどらか，また 実用面で同じと扱学るかどうか明らかではない。一つ の試みとして坪量一定で LBKP と GP の配合比を 変え抄紙した試料について触感による判定，厚さ，引 張強さ，テーバーこわさを求めて比較すると図 4 のよ らになる。触感による判定を等間隔で示すことには多 少問題はあるが GP 100\% は最も軟く，LBKP の比率 が増すにつれて急速に增加するが $50 \%$ からその影響 は少くなる。テーバーによる測定結果では紙を 15 度 曲げた場合のモーメント値として $\mathrm{S}_{15}$ で示すと LBKP 25 ：GP 75 のところに最大值があり触感とは全く一致 しない。 $\mathrm{S}_{15} / \mathrm{d}$ という厚さの補正をすることによって やや近い対応か観察される13)。このことは，EI が一 定でもこしの評価は同じではないと言うことを示唆し ている。このことは，従来の紙の評価は常にそれを弾 性体として扱っていることに一因があると思われる。
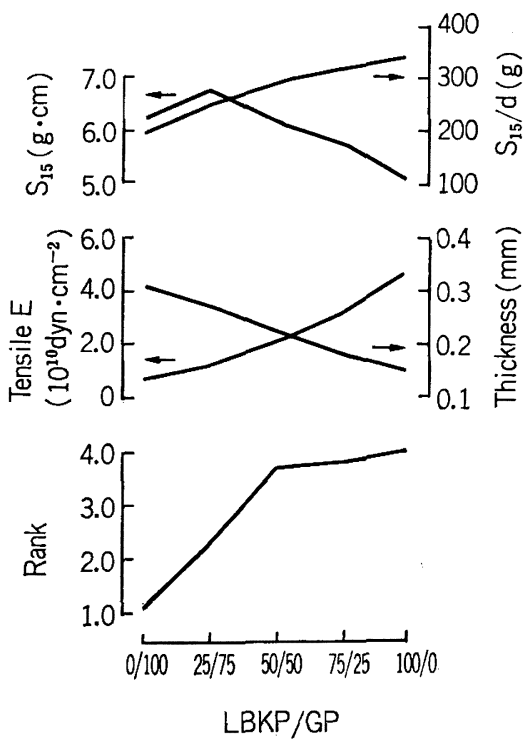

Fig. 4 Relation between sensory rank and mechanical properties of handsheets A

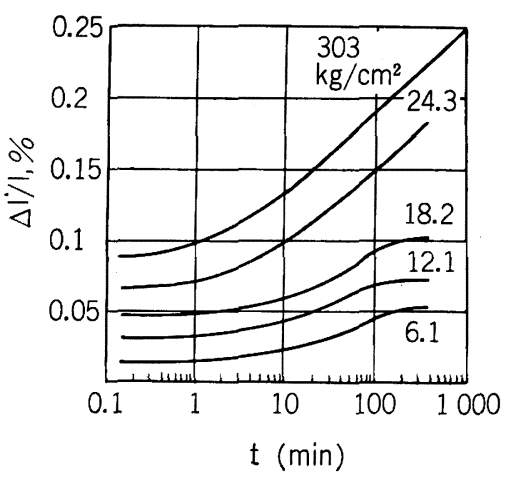

Fig. 5 Effect of load on elongational creep of printing paper in machine direction. Temp. $=30^{\circ} \mathrm{C}$. Regain $=7.7 \%$.

その最も理解しやすい例として図5のクリープ試験結 果が引用される。すなわち， $6.1 \mathrm{~kg} / \mathrm{cm}^{2} \sim 18.2 \mathrm{~kg} / \mathrm{cm}^{2}$ と言う極めて低荷重の領域での紙のクリープは荷重の 初期は瞬間弾性体として対応しているが，数分後にク リープ現象が現われ，さらに一定時間経過すると安定

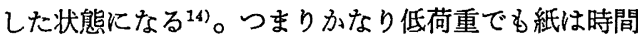
のとり方によって弾性体と塑性体との二つの挙動を示 すことを意味する。

紙を円筒に巻きつけて一端をはなすと復元する。復 元するまでの時間をライブリネス（Liveliness）と称 し布の評価にしばしば使われている。紙の場合円筒に 巻きつける時間を変えてライブリネスと前述の EI と の関係を求めると図 6 のようになる（円筒は半径 4.20 $\mathrm{cm})$ 。罒は RH $92 \%$ の高湿度下ではあるが巻きつけ

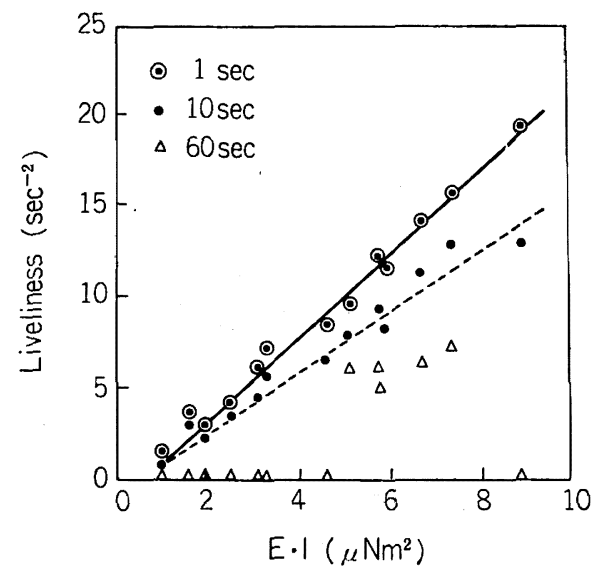

Fig. 6 Relationship between liveliness and EI at $20^{\circ} \mathrm{C}, 92 \%$ R. H. 


門 屋 卓

る時間が長くなると EI が一定でも紙はこしが無くな ってゆくことが分かる ${ }^{15)}$ 。のような現象は低含水率 でも認められ，紙を扱ら場合の一つの評価法としてこ れからの課題となるかも知れない。

\section{5. 紙の主観的評価}

はじめに述べたように，紙は各種の試験法が出現す る以前から使用されてきた。また，いくつかの例で示 したように，紙の用途によっては既存の試験機で十分 評価できないことが多い。一方，紙を永い間取扱って
表 1 Ranking of feeling by individual judgment

\begin{tabular}{ccccccc}
\hline $\begin{array}{c}\text { Basis weight } \\
\left(\mathrm{g} / \mathrm{m}^{2}\right)\end{array}$ & 58.0 & 62.5 & 69.0 & 73.2 & 79.5 & 85.2 \\
\hline $\mathrm{A}$ & 1 & 2 & 3 & 5 & 4 & 6 \\
$\mathrm{~B}$ & 1 & 2 & 3 & 4 & 5 & 6 \\
$\mathrm{C}$ & 1 & 2 & 4 & 3 & 5 & 6 \\
$\mathrm{D}$ & 1 & 2 & 3 & 4 & 6 & 5 \\
$\mathrm{E}$ & 1 & 2 & 3 & 4 & 5 & 6 \\
$\mathrm{~F}$ & 1 & 2 & 3 & 4 & 6 & 5 \\
\hline Total & 6 & 12 & 19 & 24 & 31 & 34 \\
Average & 1.0 & 2.0 & 3.2 & 4.0 & 5.2 & 5.8 \\
\hline
\end{tabular}

(A)

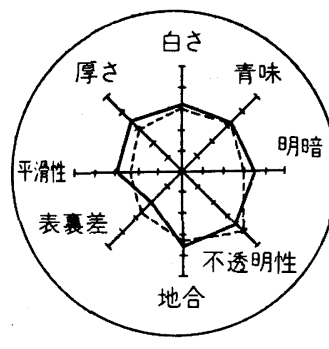

(D)

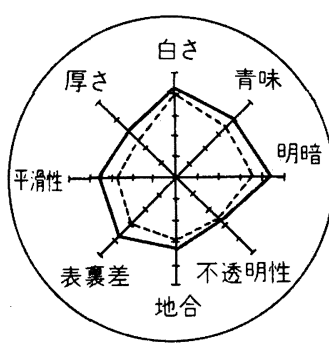

(G)

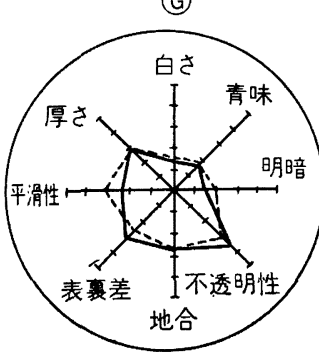

一製紙メーカー

…...ーザー
Subjective evoluation of wood free papers

(B)

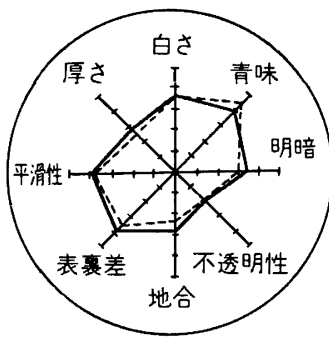

(ㄷ)

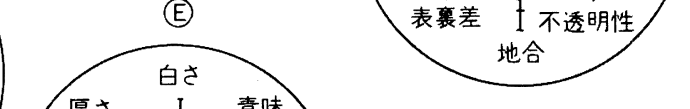

(F)

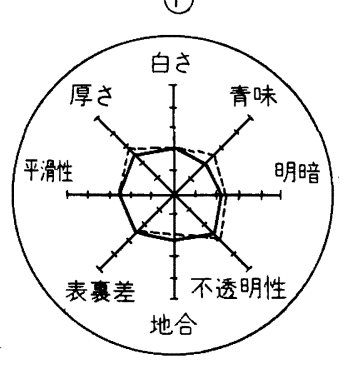

(1)

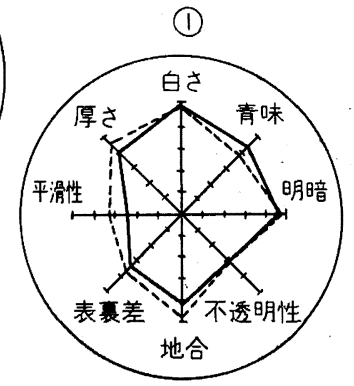

Fig. 7 
いる経験者は紙をながめ，手で触ってその紙がどんな 用途に向くかを評価していた。このような主観的な評 価がどれだけ正確に紙の姿をとらえ計器の測定值と対 応しているのか, あるいはどのような物性で今後評価 すべきかは極めて重要な課題であり興味ある研究の対 象ではないかと考える。

表 1 は NBKP の手抄き紙を坪量 $58 \mathrm{~g} / \mathrm{m}^{2} \sim 85 \mathrm{~g} / \mathrm{m}^{2}$ まで $5.0 \mathrm{~g} / \mathrm{m}^{2}$ ずつ変化させて得られた試料を 6 名の 検定者によって判定させた結果である。この場合紙の 密度, 弾性率などはほとんど変っていない。同一の原 料で抄紙法の条件が一定の場合は坪量又は厚さあるい はこしの違いを適格に区別していることが分かる。し かも低坪量の紙ほど区別の一致性がよいことは極めて 興味深い。

紙にも風合いといら言葉が時々使われることがある。 しかし，紙の風合いとは何であるかを解析した研究は 見当らない。そこで筆者等の紙の物性研究会では坪量 $64 \mathrm{~g} / \mathrm{m}^{2}$ の印刷用紙 $\mathrm{A}, 9$ 種類について 43 名の紙を取 扱っている経験者に 15 項目の判定項目をあげ 5 段階 の格付けを行ってもらった。図7は格付け順位の一致 性の高い官能検查 8 項目についてその平均点を図形化 したものである。この罒形から，それぞれの試料の特 徵が認められ印刷用紙Aといら内容にも極めて幅があ ることがらかがわれる。本項の詳細は別紙報文を参照 されたい16)。

\section{6. 紙の耐候性}

はじめに述べたよらに紙パルプの関係者とは別の分 野で資料の保存, 劣化防止と言ら課題が国際的な話題 となっている。

我が国に括いても書籍 380 万冊，定期刊行物も含め て 700 万部の蔵書を有する国会図書館で崩壊が激しく 借出しを停止している書物があると聞いている。

この問題に関しては新聞やラジオ，テレビなどでと りあげられ耐候性についての学術論文も幾つか見当る

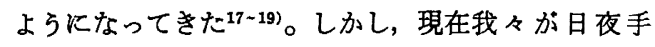
にしている紙がどの程度劣化が進行し, あと何年持つ のかと言ら点になると推測することは極めて難かしい。 電子分光法によって表面の状態を測定した例はある が20)詳細な研究は今後の課題である。さらに紙を含め た印刷物といら対象になると体形的な研究はさらに少 ない。

中性紙, 酸性紙の問題については改めて触れること にして，図書館の関係者等が紙が“ボロボロになる” という表現はどのような感覚で受け止めているかしら へてみた。表 2 は現在図書館担当者でとりきめた紙の
表 2 紙の少化基準 (Subjective Standard of Degradation of Paper in Japan)

\begin{tabular}{|c|c|c|c|}
\hline \multicolumn{3}{|c|}{ 紙 の 劣 化 の 状 態 } & 点数 \\
\hline \multirow[b]{2}{*}{ 少 } & Excellent & 非常に良好な状態。 & $4 x$ \\
\hline & Good & $\begin{array}{l}\text { しなやかで, 折り曲げても簡 } \\
\text { 単には折目のつかい状態。 } \\
\text { 俥く折り曲げると, 元に戻ろ } \\
\text { らとする。弾力性有り。 }\end{array}$ & 3 \\
\hline 化 & Fair & $\begin{array}{l}\text { 折り曲げると, 折り目はつく } \\
\text { が,切れてしまらことない } \\
\text { 状態。 } \\
\text { 折り曲げると, 折れないが元 } \\
\text { に戻ろうとしない。弾力性無 } \\
\text { し。 }\end{array}$ & 2 \\
\hline 合 & Brittle & $\begin{array}{l}\text { 折り曲げると，切れてしまう } \\
\text { 状態。 } \\
\text { 逆曲げするときれる。実験で } \\
\text { そうなったすの。 }\end{array}$ & 1 \\
\hline & $\begin{array}{l}\text { Very } \\
\text { Brittle }\end{array}$ & $\begin{array}{l}\text { 崩れかかっている状態。 } \\
\text { 既にそらなったもの。 }\end{array}$ & 0 \\
\hline 変 & \multicolumn{2}{|c|}{$\begin{array}{l}\text { 変色のないものから, 中程度の変色（周 } \\
\text { 苒けけ変色)。 }\end{array}$} & 0 \\
\hline 度 & \multicolumn{2}{|c|}{$\begin{array}{l}\text { 甚しい変色（队部にまで変色が進んでい } \\
\text { る)。 }\end{array}$} & \\
\hline
\end{tabular}

劣化状態の基準である。この基準は米国のミシガン大 学で行っている判定基準を国会図書館が倹討して1983 年秋の国会で報告され, 以後我が国の一部の図書館で 引用されているとのことである。

紙の劣化の程度を定量的に求める方法として現在耐 折強さが最も有意差が得られる方法として使われてい る。しかしこの方法は個々の測定値の変動か゚烈しく， 少数の試片では信頼性に欠ける問題がある。一方，表 2 の判定はあくまでも主観的評価であり，これを耐折 強さで測定したとしたらどのような值と対応するか， 今のところ全く明らかになっていない。

また，現在試料の耐候性の判定は Tappi スタンダ ードでは $105^{\circ} \mathrm{C}, 72$ 時間処理した試料の耐折強度で表 わし，自然放置下の 24 年に相当するとしている。し かし, 最近 Luner の研究で知られるように $80^{\circ} \mathrm{C}$ の 中温下でも相対湿度が高い環境に紙を放置した場合は

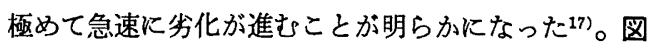
8 は彼の報告の一部を示した。これから明らかなよら に環境湿度が高くなればなるほど劣化が促進し， RH $81 \%$ の場合は 17 日程度で強度がゼロになってしまう。

現在我が国の紙の製造は原料は国外から仰ぎ，古紙 を大量にリサイクルし，抄紙技術も以前とは種々な点 で変ってきている。また，中性抄紙も次第に普及化し 


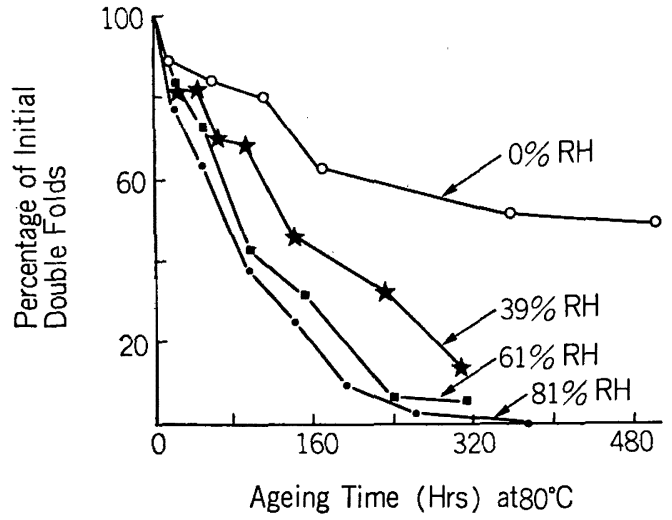

Fig. 8 Effect of humidity of folding endurance (bond paper aged at $80^{\circ} \mathrm{C}$ )

てきているが，これらの紙が耐候性という点でどの辺 に位置づけられるのか評価された資料はほとんど見当 らない。紙の劣化についてはまだ不明の点が多くこれ からの研究課題ではないかと考える。

\section{7. むすび}

以上，紙の評価という観点で幾つかの事例をとりあ げ考察してみた。紙が世の中に存在しそれが多種多様 に使われている限り，それを正確に評価することは極 めて重要なことであるが敩密に追究してゆくとまだ多 くの問題が残されている。今回の事例にはとりあげな かったが，紙の導電性なども正しい評価をするために はさらに追究する余地が数多くあると思われ，JIS そ のものも矛盾の点が多い211。

今回は出来上った紙を対象として，その評価につい て述べたが当然原料であるパルプ，およびその周辺の 物理, 化学的評価も重要なことであり,これについて は何れ機会を見て述べて見たい。

\section{引用文献}

1）紙及びパルプ年表. 昭和 49 年，紙パルプ技術協会 編.

2) Pulp and Paper Manufacture, vol. 3, p. 838, 1953 McGraw-Hill.

3) A. R. Urquhart and A.M. Williams, J. Textil Inst. 15, T 559 (1924).

4) R. T. Skogman and C. E. Scheie, Tappi, 489, 1977.

5) D. L. Taylor, Tappi, 47, 7, 165 A, 1964.

6) R. B. Wasser, Tappi, 57, 166, 1974.

7) T. Uesaka, K. Murakami and R. Imamura, Tappi, 62, 1, 1974.

8）木村, 小田, 岩崎, 門屋, 木材学会誌. 25, 2, 140, 1979.

9）小田，門屋，臼田，木村，紙八゚技協誌. 33，3， 214, 1979.

10) V.C. Setterholm, Tappi, 57, 3, 164, 1974.

11) J. dA. Clark, Paper Trade J. Mar. 28, 41, 1935.

12) I.P.C., Paper Trade J., Feb., 15, 29, 1940.

13）数森, 内藤, 臼田, 門屋, 紙パ技協誌. 35, 8, $703,1981$.

14）広瀬，柘植，和田，応用物理. 30，6，417，1961.

15）加藤, 内藤， 臼田，門屋，紙パ技協誌. 37，5， 430, 1983.

16）岡川章夫，計測と制御. $23 ， 3 ， 306,1984$.

17) P. Luner and P.D. Cardwell, "The Fundamental Properties of Paper Related to Its Uses. p. 724, 1976.

18）門屋 卓, 古文化財の科学. $26,81,1981$.

19）臼田誠人，紙八技協誌. 38，1，48，1984.

20) 門屋 卓, 古文化財に関する保存科学と人文自然 科学, 昭和57年度年次報告 p. 134, 昭和58年 3 月.

21) 門屋 卓, 繊維学会第14回夏期セミナーテキスト p. $54,1982$. 